Recruiting For Success. Does Board Diversity Matter?

\title{
RECRUITING FOR SUCCESS. DOES BOARD DIVERSITY MATTER?
}

Meg E. Cotter Mazzola, Joseph L. Pontacoloni, Angel Claudio, Javier A. Salguero, Marcelles James, and Robert M. Yawson.

School of Business, Quinnipiac University

\begin{abstract}
Nonprofits play an essential role in society. To realize their important missions, nonprofits rely on strong and committed leaders at both the organization level as well as the governance level. Nonprofits are obligated to have an active board of directors to operate. This reliance places the organization in a vulnerable position where they must recruit and engage with external stakeholders and identify individuals with the combination of talent needed to succeed as well as the passion for supporting the organization's vision. Knowing that board members have a longlasting impact on their organizations, this paper looks at the varying models of governance and the implications for choosing one model over another. Determining the best structure for a governance model represents one component to setting an organization up for success. Equally, if not more important, is ensuring that the board of directors is composed of motivated and committed individuals who are steadfast in their efforts to support the mission of the organization. In order to find the best people for the role, an organization must understand what drives and motivates an individual to serve on a board. The topic of motivation as it relates to governance boards, and how existing boards can use the motivating factors to recruit and retain board members is explored. Finally, we explore the value of diverse board composition and whether certain criteria of diversity carry more weight in terms of impact than others.
\end{abstract}

Keywords: Recruitment, Diversity, Governing Boards, Nonprofits, Motivation 


\section{MODELS OF GOVERNANCE}

A board of directors is typically a formal construct that provides governance for the company or organization. Members of the governing board are directors of the corporation under the law (Worth, 2019). Because nonprofit governing boards are not all the same, they have different implications for how they operate and bring forth organizational affairs to their governing boards and their CEOs. Governance practices are measures of board effectiveness as these practices reflect the board's capacity to perform various functions and competencies (Buse, Bernstein \& Bilimoria, 2016). There are several and important responsibilities the governing board must achieve. First, they appoint, support, and evaluate the CEO of the organization. Governing boards establish a clear institutional mission and purpose, approve the organization's programs, ensure sound fiscal management and the organization's financial stability, and create standards for organizational performance to hold the organization accountable (Yawson, 2019).

There are different board governance model's nonprofit organizations use to implement internally. We examined these models and their purposes. Worth (2019) provides examples of the models of governing boards that are common to find in nonprofit organizations; they are elected governing boards, self-perpetuating governing boards, hybrid governing boards, and advisory councils. Furthermore, we examine the patron model, which its focus is on fundraising activities. Each of these models has compelling advantages and disadvantages. In the following sections we discuss the various models.

\section{Elected Boards}

A nominating committee of the existing board introduces and recommends nominees who will often be approved by the board of directors to obtain membership via a formal vote. Existing board members can vote via mail, email, and often in annual meetings. An advantage of this type of board is that the CEO may serve as a strong advocate for the nominee and be reactive to the members' needs and concerns (Worth, 2019). A disadvantage of this board is the fast turnover it can implicate on the governing board, which can hinder long-term goals and plans of the organization.

The American Red Cross is an example of the elected board model. A Governance and Board Development Committee is responsible for assessing the Board's skill set requirements and needs against a pre-determined set of criteria. The Committee then follows a six-step process to identify candidates, interview candidates, and nominate candidates. The final step is a 
recommendation by the Committee to the full Board for a vote. If approved, the candidates will be presented to the delegates of the American Red Cross at the annual meeting. (www.redcross.org)

\section{Self-perpetuating Boards}

This structure is prevalent among the 501(c)(3) charitable nonprofit boards. This governing board is similar to the elected boards in which members are elected by existing members of the board (Worth, 2019). However, self-perpetuating boards create stable situations for the nonprofit organization (NPO) and its CEO. They tend to have longer terms than elected boards, and the board's membership often changes slowly. In contrast to corporations with boards elected by voting members, charities are governed by self-perpetuating boards. In other words, in this type of board, members vote for their successor. An advantage of this type of board is the continuity of culture and priorities and organizational strategic goals. It also allows the recruitment of new members with needed skill sets that may benefit the board of directors. One crucial disadvantage, however, is that in this structure, the governing board may stay complacent in terms of responding to new changes in the revolving environment and yield too much authority to the CEO.

\section{Hybrid Governing Boards}

This type of board is emerging in leading-edge nonprofits. It addresses the weaknesses identified in other approaches through judicious use of committees structured around the board, rather than management, responsibilities (Gill, 2007). In this type of model, the governing board members seek the appointment of individuals externally. This model is typically used in public organizations; for example, the governor of the state often appoints the board of a state university. Another example of this board can be found in religious congregations and health care organizations such as Medicaid and Medicare (Worth, 2019). In hybrid governing boards, members can be elected, and some can be appointed or serve ex-officio. Worth (2019) proposes that ex-officio "is designated to be held by the individual who holds a certain office or position" (p. 85).

\section{Advisory Councils}

These councils do not have the legal authority nor the responsibility for governance in the organization. Instead, they provide guidance and advice to the board of directors in expertise in finance [fundraising], operations orientation and strategic goal transparency, and law or the industry with which the organization is affiliated. There are several reasons why these advisory councils are created within the governing board. Advisory councils of experts can provide 
substantive advice on the organization's programs as well as advice on current clients and stakeholders who provide feedback on the effectiveness of programs from a different perspective (Worth, 2019). When situations raise questions, the board can turn to the advisory council for advice and seek assistance and guidance through organizational issues. Thus, the importance of a diverse council ensures the success of the organization overall.

\section{Patron Model}

The patron model serves for the particular purpose of fundraising. Its primary activities are to arrange, facilitate, and participate in fundraising activities. Thus, the board is primarily selected from a pool of wealthy and influential individuals in the community who contribute their own funds and solicit funds through their personal and business networks (Price, 2018).

\section{MOTIVATING FACTORS FOR BOARD ENGAGEMENT}

Nonprofits need to understand the reasons why individuals join and continue to serve on nonprofit boards. Understanding what motivates these individuals will help focus the boards' recruitment efforts (Milde \& Yawson, 2017). Once the board understands the motivators, it can create an incentive plan targeting these specific motivators and individuals. Since nonprofits and for-profits are in direct competition for board members, should their recruitment policy be similar to for-profit recruitment policy? Understanding "why board members volunteer to serve on nonprofit boards will help nonprofit organizations attract and retain the best board members" (Miller-Stevens \& Ward, 2019, p. 3).

Board participation is voluntary, so why serve? "Studies have found that people cite volunteering out of a sense of duty or commitment to a specific mission or public good" (MillerStevens \& Ward, 2019, p. 63). According to Herzberg's need theory, motivators and dissatisfiers are factors that influence motivation (Worth, 2019). Commitment to a specific mission or public good can be described as an intrinsic motivational factor since it "relates to individual feelings and the nature of the job itself" (Worth, 2019, p. 249).

"Research also shows that many people volunteer because they have been asked to do so by others or because they desire social recognition for their good deeds" (Miller-Stevens \& Ward, 2019, p. 63). Social acknowledgment and acceptance are also intrinsic motivators as they satisfy the need for recognition. In addition, McClelland's Three Needs Theory identifies "three principal needs that people have: the need for achievement, the need for power over others, the need for affiliation or good relationships with others" (Worth, 2019, p. 249). The need for affiliation or 


\section{Recruiting For Success. Does Board Diversity Matter?}

good relationships with others can help explain why an individual may choose to accept an invitation to serve on a board.

It has also been argued "that individuals who volunteer may be inspired by an impure altruism, in that they possess a desire to help others but also are driven by the potential for personal gain" (Miller-Stevens \& Ward, 2019, p. 63). Maslow's hierarchy of needs theory describes this as the need for self-esteem. "Maslow's (1954) theory states that human needs progress as the lowerlevel needs are met" (Worth, 2019, p. 246). There are five levels in Maslow's Hierarchy of Needs: physiological, safety, love, esteem (ego), and self-actualization (Worth, 2019). The individual is using volunteerism to satisfy their needs for self-esteem, also known as ego. These motivational factors can also explain why individuals choose to continue to serve on nonprofit boards.

While these motivating factors can be used to explain why individuals choose to volunteer in the nonprofit sector, it does not fully explain why an individual would want to participate on a governance board. "It's important to consider the reasons why individuals may be attracted to participate in a governance role that is situated at the top of the organizational chart" (MillerStevens \& Ward, 2019, p. 63). Miller-Stevens \& Ward (2019) further suggest that there are three reasons why leaders serve on nonprofit boards, the democratic model of leadership, the oligarchic model of leadership, and the leadership by default model.

- First, "the democratic model of leadership views leaders as individuals who aspire to such positions but who also value decentralization of power and are driven by the goal of serving the organization and contributing to its success" (Miller-Stevens \& Ward, 2019, p. 64).

- Second, "the oligarchic model of leadership views aspiring leaders as coming from a small network of individuals who maintain control over knowledge and power in the organization and are more motivated by self-recognition than the organization's mission" (MillerStevens \& Ward, 2019, p. 64).

- Third, "in the leadership by default model, there is a lack of interest among all organization members to lead, and those who end up in leadership roles are chosen because they may have a stronger commitment to the organization's goals" (Miller-Stevens \& Ward, 2019, p. 64).

The models described provide insight as to reasons why leaders begin their tenure on nonprofit boards. The question of what factors motivate leaders to remain on nonprofit boards remains. A study conducted by Miller-Stevens \& Ward (2019) recognized eight factors ranging 
from a rating of important to critically important. These factors are: "serving the organization and contributing to its success, having a sense of duty/commitment to the mission, being helpful to others, because they really want to help the particular group that the organization serves, out of loyalty and respect for the organization, to contribute to society, to share their expertise and professional skills, and to learn more about the organization and the cause it supports" (MillerStevens \& Ward, 2019, p. 71). Out of these factors, only one was unique to continued service, learning more about the organization and the cause it supports.

\section{NONPROFIT VS. FOR-PROFIT BOARD RECRUITMENT}

"The dramatic growth in the number of nonprofit organizations over the past decade means that a greater number of board members are needed, which may contribute to greater competition in recruitment" (Ostrower, 2007, p. 7). Not only is there an increased demand for a higher number of board members, but there is also an increasing focus and call for board diversity. "High levels of ethnic homogeneity on many boards raise questions about nonprofit boards' ability to be responsive to the diversity of the constituencies served by their nonprofits" (Ostrower, 2007, p. 8). "Most previous research on nonprofit boards concludes that they are largely white, male, and upper-middle-class (Ostrower, 2007, p. 23). The increased need for recruiting a board that is both diverse in gender and ethnicity is highly sought after by both for-profit and nonprofit boards. However, if nonprofit boards are competing amongst themselves for diverse representation on the board, how can nonprofit boards, drawing from the same candidate pool as for-profits, compete to find individuals with the criteria they need?

Nonprofit organizations cannot rely on the same board recruitment policies as for-profits because their purpose and missions are different. The lack of a driving focus on profit as the critical measure of success is the starkest difference between for-profits and nonprofit organizations (Horobiowski, 2004, p. 56). There is a common perception that nonprofit organizations should not make a profit, nor should they offer compensation to their board members and staff. Doing so would raise questions of conflict of interest and ethical violations. In his research, Ostrower presents data on board compensation and finds a low percentage in compensation in nonprofit organizations of the ones he researched. Additionally, he finds no evidence that compensating trustees help nonprofits attract board members with particular expertise (Ostrower, 2007, p. 11). "Without a clear financial bottom line, nonprofit organizations rely on the mission to attract resources and guide decision making," (Guo, Brown, Ashcraft, Yoshioka \& Dong, 2011, p. 250). 
As a result, mission statements are recognized as a robust management tool that serve to motivate nonprofit employees as well as board members and keep them focused and engaged on the organization's purpose (Guo et al., 2011, p. 250).

Another notable difference between for-profit and nonprofit boards is the strategy behind board composition, specifically for-profits awareness of the benefits of a diverse board. Nonprofit organizations tend to have homogeneous boards, whereas "for-profit boards are typically built with the opposite in mind" (Horobiowski, 2004, p. 59). This is a place where nonprofits can learn from for-profit strategy and focus on acquiring specific diversity attributes to help reduce board homogeneity.

\section{Defining Diversity}

For the purposes of this study, board diversity is defined as various compositions of the board of directors and their direct observance of aspects, i.e., gender, age, race, and ethnicity. And less visible aspects, for example, education and work experience. The questions surrounding the implications and impact of board composition represent a growing field of research. As mentioned by Ostrower (2007),

Most previous research on nonprofit boards concludes that they are largely white, male, and upper-middle and upper class. These studies focused primarily on large nonprofits, and thus, a major question for this study was whether or not a more heterogeneous picture would emerge from looking at a more representative array of nonprofits. (p. 23).

The findings of Ostrower's work suggest a positive association between board member diversity and inclusion in terms of gender and racially diverse membership, leads nonprofit organizations to increased performance and agency success. Studies have discovered less diverse boards have increased difficulty to the varied needs of the population they serve (Forbes, 2015). These findings further highlight the need for recruitment strategies that include diversity.

Seven years after Ostrower's work, a study conducted by Harris examined the impact of board of director characteristics on nonprofit performance. While the study was limited in its size, results indicate that both board member diversity and expertise are associated with betterperforming organizations (Harris, 2014). Harris's findings supported those of prior research on the topic. BoardSource (1999) reported that heterogeneity in groups promotes creativity and innovation, noting that the need for diversity is an essential part of making effective decisions and delivering appropriate services to minority clients (Harris, 2014). Furthermore, Katmon, 
Mohamad, Norwani \& Farooque, 2019) suggest the importance of board diversity can be explained from the theoretical perspective using the resource-based view theory (RBV), given the fact that, as part of an organization's strategic decision, board diversity signifies "core competence or dynamic capability.",

\section{Impact of attributes}

Board diversity plays a vital role in the "discretion and decision-making process of the board, which are mainly derived from their personal (i.e., gender, ethnicity, nationality, age) and professional (i.e., education level, educational background, tenure) contexts" Katmon et al. (2019, p.448). "Organizations need diverse boards because of the important functions the board serves. Specifically, the board makes strategic decisions, develops links with external stakeholders, and helps engage talent from the labor market" (Ali, Ng \& Kulik, 2014, p. 498). Katmon et al. (2019) consider board diversity to be a cornerstone to the "board uniqueness in line with the resourcebased view (RBV) theory that supports the knowledge, intelligence and expertise of a heterogeneous group of board members as valuable firm resources" (p. 450). "The resource-based view (RBV) argues that when a firm's resources are economically valuable (exploiting opportunities and neutralizing threats), relatively rare, difficult to imitate, and imperfectly mobile across firms (remaining bound and available), they can explain the differences in firm performance" (Ruivo, Oliveira \& Neto, p. 106). Board diversity is a valuable organizational resource that is relatively rare and difficult to imitate; in consequence, the owning organization is able to develop a unique competitive advantage. To take full advantage of board diversity, an organization needs to understand how the attributes of personal and professional diversity impact board performance.

\section{Personal Attributes (i.e., gender, ethnicity, nationality, age)}

\section{Gender}

Gender diversity "promotes a better understanding of the marketplace, thereby increasing its ability to penetrate markets" (Gallego-Álvarez, García-Sánchez \& Rodríguez-Dominguez, 2019, p. 58). Gender diversity "enhances creativity and innovation and leads to more effective problem-solving since a more diverse board provides a wider variety of perspectives and, consequently, a higher number of alternatives to evaluate" (Gallego-Álvarez, García-Sánchez \& Rodríguez-Dominguez, 2019, p. 58). Furthermore, it "may issue positive signals to markets labor, products, and capital markets - by providing a greater degree of legitimacy to corporations 
and improving their reputations" (Gallego-Álvarez, García-Sánchez \& Rodríguez-Dominguez, 2019 , p. 58). Lastly, "the RBV theory is that synergies between male and female interaction in the board are valuable" (Katmon et al., 2019, p. 453). Some of the disadvantages of gender diversity are that the teams "communicate less frequently, are usually less cooperative, and experience more conflicts" (Gallego-Álvarez, García-Sánchez \& Rodríguez-Dominguez, 2019, p. 58). In addition, it may lead to a slower decision-making process due to the difference in leadership styles between men and women. Furthermore, increased conflict may generate more opinions and critical questions, which might enhance the overall work, but it may also delay the board's proceedings (Gallego-Álvarez, García-Sánchez \& Rodríguez-Dominguez, 2019).

\section{Ethnicity}

Watson \& Kumar (1992) suggest that "culturally diverse groups have the potential to generate a greater variety of ideas and other resources than culturally homogeneous groups" (p. 61). However, these multicultural groups have specific challenges to overcome before they reach their potential. For instance, they face problems such as "inability to communicate clearly, frequent disagreements on expectations, and attitudinal problems such as dislike, mistrust, and lack of cohesion" (Watson \& Kumar, 1992, p. 54). If the group can overcome these problems, they have the potential to reach peak efficiency and effectiveness. Racial diversity in the board is viewed as valuable and has the potential to provide the company with a competitive edge (Katmon et al., 2019). The reason it creates a competitive edge is that "each culture carries its own set of values, norms, beliefs, or behaviors that shape their worldview which, to a certain extent, will influence their moral conduct and strategic decisions" (Katmon et al., 2019, p. 456).

\section{Nationality}

National culture has been found to have an enduring impact on executive mindsets and interpretation and response to strategic issues. These "cultural patterns of thinking, feeling, and acting are acquired in early childhood because at that time a person is most susceptible to learning and assimilation" (Nielsen \& Nielsen, 2013, p. 374). "The RBV theory recognizes the presence of international human resources as one of the most valuable, unique and difficult-to-imitate resources owned by the firm. With an increase in business diversification, firms need dynamic resources to cater for international markets in order to achieve competitive advantage" (Katmon et al., 2019, p. 456). While there are benefits to having an internationally diverse board, it does have some disadvantages. For example, "the presence of foreign directors may impair the internal 
governance due to a lower number of board meetings, thus signaling weak monitoring roles by the board" (Katmon, et al., 2019, p. 456). In addition, "the presence of different nationalities on boards may also lead to cross-cultural communication problems" (Katmon et al., 2019, p. 456). Nationality and ethnicity are closely related; therefore, we see the emergence of similar challenges for the board.

Age

"High board age diversity is associated with large donations for not-for-profit organizations and high return on assets in the case of for-profit organizations" (Ali, Ng, \& Kulik, 2014, p. 498). An age-diverse board "can integrate a wider range of information to make more informed decisions" (Ali, Ng, \& Kulik, 2014, p. 499). Research has found, "younger directors tend to be highly educated and familiar with new technologies, whereas; older directors bring to the board valuable experience that they accumulated in the industry" (Ali, Ng, \& Kulik, 2014, p. 499). The organization can leverage these complementary attributes to improve its strategic decision making (Ali, Ng, \& Kulik, 2014, p. 499). "Diversity in board members' age will lead to variation in values and perspectives since each generation is unique and special in the sense that their worldview is developed according to different experiences, social, political and economic environments, and events" (Katmon et al., 2019, p. 455). However, while different values and perspectives can be a positive, these differences "might lead to either the board efficiency or inefficiency in decisionmaking processes due to different levels of worldview experience and upbringing" (Katmon et al., 2019, p. 455). Minus the impact on decision making, these differing viewpoints create value and competitive advantage for the organization.

\section{Professional Attributes (i.e., education level, educational background, tenure)}

\section{Educational Level}

The firm can exploit a diverse board educational level in order to help the board in making strategic decisions to achieve a competitive advantage (Katmon et al., 2019). "Educational level shapes an individual's cognitive base and leads to a better ability to process information and ability to absorb new ideas" (Katmon et al., 2019, p. 454). There are both advantages and disadvantages of lower and higher levels of educational level diversity. Directors with lower levels of education have the opportunity to gain experience not taught in the classroom, whereas directors with higher educational levels may be tied to a specific depth of knowledge, which limits the absorption of new ideas (Katmon et al., 2019). Furthermore, higher educational level directors have created 
Recruiting For Success. Does Board Diversity Matter?

social ties and networking links with other "university/alumni who one day become the main market players in the capital market and regulatory institutions" (Katmon et al., 2019, p. 454). These connections, according to the RBV theory, are valuable, rare, and hard to imitate. While lower-level educational directors may lack contributions tied to a formal educational background, they might be in a unique position to contribute a thorough amount of practical experience. Having a balance of educational and practical experiences represented on the board helps to create a "variety of opinions, perspectives, and experiences" (Katmon et al., 2019, p. 454). Ultimately, having various educational levels represented on the board will favorably influence the value of the decisions made by the board.

\section{Educational Background}

Studies have shown that an organization benefits from both a board's varying levels of education as well as a diverse field of academic knowledge. "Diversity of knowledge and ability of the board members derived from different educational background is crucial to speed up the strategic decision making, to improve board effectiveness in evaluating strategic implementation, to share knowledge and generate new knowledge, and to reduce the problem bounded rationality" (Katmon et al., 2019, p. 454). To facilitate robust discussions on different areas of expertise, the board requires members with multiple educational backgrounds before it can make efficient and effective strategic decisions. Having various educational backgrounds brings differences in individual attitude and intelligence and cognitive base that might be beneficial in improving the quality of innovation and decision making from various perspectives (Katmon et al., 2019).

\section{Tenure}

"Board tenure refers to the length of time directors hold directorship positions in the organization" (Katmon et al., 2019, p. 455). Again, there are advantages and disadvantages to having a board with long-tenured members. First, long board tenure has an advantage as directors have more considerable experience and expertise with the company's policies and monitoring and reporting process (Katmon et al., 2019, p. 455). In addition, "longer board tenure is associated with lower levels of misleading information and disclosure," increased ability to build organizationspecific expertise, and are known as reputable and knowledgeable members of the organization (Katmon et al., 2019, p. 455). Some disadvantages of long-tenured board members are they may be unlikely or hesitant to undertake innovative activities, they often remain in their comfort zones, and repeat the same process (Katmon et al., 2019). These disadvantages, also evident in CEO 
tenure, have a negative impact on organizational progress and change. The correlation between tenure and organizational change is attributed "to the fact that CEOs become extremely committed to their previously enacted strategic plans, avoidance of information that disconfirms their plans, having decreased interest in their present jobs, and having the power that enables them to avoid demand for change" (Buse, Bernstein, \& Bilimoria, 2016, p. 1-2). These same tenure diversity pitfalls could impact the performance of nonprofits boards. Therefore, board tenure diversity would be advantageous for organizations as "companies with diverse board member tenure perform better than boards with homogeneous tenure" (Katmon et al., 2019, p. 455).

Board Size

Research suggests a positive correlation between board size and nonprofit performance. Specifically, larger boards allow board members the opportunity to take on certain smaller tasks so that one person does not feel pressure to accomplish the organizations' goals alone. The exception is in healthcare, where networks such as hospitals take in a majority of their payments from commercial insurance companies opening the possibility for board members to abuse their power and influence the decision making (Aggarwal, Aggarwal, Evans \& Nanda, 2012).

Based on our review of the literature, it does not appear that there is a direct number associated with what is considered to be a large board or a small board. It is only viewed that the larger the Board, the more "positively related to the number of programs pursued, revenue generated, and expenditure on programs" (Bai, 2013, p. 173). A study was conducted with nonprofit and for-profit hospitals in California that did provide some insight to the board size. This was used as our example to review what nonprofit organizations have quantitative data like the state of California requires hospitals to report on three pieces of information: operational, financial, and governance to the Office of Statewide Health Planning and Development (OSHPD) (Bai, 2013). On average, nonprofits had 15 directors, while for-profits had 9 (Bai, 2013). The results from this study supports our conclusion that a larger board size is more beneficial for nonprofit organizations.

\section{RECRUITING FOR DIVERSITY}

Nonprofit organizations, like for-profit organizations, seek to recruit for diversity for several reasons: to forecast labor shortages, to increase minority representation to avoid legal scrutiny, to enhance their public image, to gain access to minority customers, and to increase organizational creativity and innovation (Mckay \& Avery, 2005). "Diversity recruitment strategies 
vary a great deal. So-called successful tactics include the use of recruitment advertisement photographs that depict a diverse workforce, minority recruiters, and communicating adherence to identity conscious staffing policies" (Mckay \& Avery, 2005, p. 332). The goal of these efforts is to create a positive perception that the recruiting organization values diversity (Mckay \& Avery, 2005). The challenge organizations face is that the positive perception presented to candidates may not be the reality within the organization. So, while the firm may be able to recruit the candidate, it may not be able to retain that employee or board member because perception and reality do not match.

To successfully recruit for diversity, organizations need to "obtain upper management endorsement of diversity initiatives and create corporate policies that support workplace diversity" (Mckay \& Avery, 2005, p. 333). By obtaining this type of support, organizations ensure the success of their diversity initiatives and policies. McKay \& Avery (2005) suggest that organizations take several steps before they begin to recruit for diversity. These steps include a diversity audit, diversity training, recruitment planning and implementation, and recruitment evaluation.

- Diversity audit: "A diversity audit can provide several key pieces of information useful in designing minority recruitment initiatives."

- Diversity training: "Diversity training is designed to sensitize organizational members to subconscious biases and prejudices that foster discriminatory behavior."

- Recruitment planning: "Organizational leaders should develop an action plan for targeting sources of minority applicants. Several sources of these include predominantly minority colleges and universities or regional/notational meetings of minority professional organizations."

- Recruitment implementation: "Information collected during diversity audits should form the basis of diversity recruitment implementation. The nature of diversity climate and organizational demographic data can be used to form the basis of the recruitment messages."

- Recruitment evaluation: "Diversity recruitment initiatives should be evaluated for their effectiveness. These efforts should be assessed on their level of minority hiring and retention."

As indicated earlier, the purpose of recruiting for diversity is to enhance creativity and innovation to facilitate practical problem-solving while providing a "wider variety of perspectives 
and, consequently, a higher number of alternatives to evaluate" (Gallego-Álvarez, GarcíaSánchez \& Rodríguez-Dominguez, 2019, p. 58). Incentives do not support this mission because rewards are the enemy of exploration and creativity (Kohn, 1993). The reason rewards kill creativity is because "when we are motivated by incentives, features such as predictability and simplicity are desirable, since the primary focus associated with this orientation is to get through the task expediently in order to reach the desired goal” (Kohn, 1993).

"Financial incentives and controls become less effective, as many individuals in nonprofits regard money as a means to achieve larger purposes and not as an end in itself, either professionally or organizationally" (Guo et al., 2011, p. 250). Nonprofit organizations should not employ incentive tactics to recruit and retain diverse board members. Instead, nonprofits should use strategies that draw on individuals' intrinsic motivations rather than on the extrinsic motivation of rewards such as money (Guo et al., 2011, p. 251).

\section{BENEFITS AND CHALLENGES OF A DIVERSE BOARD}

Organizations with diverse leaders and employees have a competitive advantage over homogeneous organizations. Horowitz \& Horowitz (2007) support this theory finding that different backgrounds and experiences can lead to improved results. Providing opportunities for individuals to bring their diverse expertise and knowledge forward improves internal operations in several ways. Having individuals relate their experience to help overcome issues at hand is known as cognitive diversity. It is defined as "the degree to which team members differ in terms of expertise, experiences, and perspectives" (Horowitz \& Horowitz, 2007, p. 989). This promotes "creativity, innovation, and problem solving, and thus results in superior performance" (p. 989). A second benefit is a likelihood that diverse boards are more concerned with ethical practices and own a responsibility to take action to reduce perceived risks (Kamon, Monhamad, Norwani \& Faroque, 2017). Additionally, diversity among board members improves "the quality of corporate decisions, offering better problem solving, increasing organizational competitiveness and providing new insights that lead to innovation" (Kamon et al., 2017, p. 452).

Diverse board membership does not come without its challenges. One particular item to be aware of is when board members have a professional stake in a for-profit company while serving on a nonprofit board. There is a possibility of that member using their influence for their benefit. The Sarbanes-Oxley Act of 2002 is a federal law that established auditing and financial regulations to deter fraud (Ostrower, 2007). As a result, the industry has become more scrutinized because 
nonprofit organizations today are feeling pressure to become more accountable and transparent to the public, changing the way policies and procedures are developed within the organization (Ostrower, 2007).

\section{RECOMMENDATIONS \& CONCLUSION}

Nonprofits must contend with a number of constraints to exist and ultimately to thrive. Members of nonprofit governing boards are armed with the responsibility to safeguard their organizations' missions and provide value and support to the short-term and long-term goals of the organization. This undertaking imposes both careful and continuous thought and strategy into the overall board composition.

While the existing body of research on the impact of board diversity on organization performance is limited, we do find evidence of a positive association between board member diversity and inclusion, in terms of gender and racially diverse membership, as well as other attributes including individual's perspective and overall board size, leads nonprofit organizations to increased performance and agency success. In addition, research studies have discovered less diverse boards have increased difficulty to the varied needs of the population they serve.

Consequently, the want and need to recruit and retain capable and committed members of the board merits a comprehensive approach to identify a broad range of talent and expertise. By taking a proactive approach to board diversity, organizations can support not only the motivations of their members but also the long term value of the organization itself. 
Recruiting For Success. Does Board Diversity Matter?

\section{REFERENCES}

Aggarwal, R. K., Aggarwal, R. K., Evans, M. E., \& Nanda, D. (2012). Nonprofit boards: Size, performance and managerial incentives. Journal of Accounting \& Economics, 53(1-2), 466-487.

Ali, M., Ng, Y. L., \& Kulik, C. T. (2014). Board age and gender diversity: A test of competing linear and curvilinear predictions. Journal of Business Ethics, 125(3), 497-512 doi:10.1007/s10551-013-1930-9

American Red Cross Board of Governors Nominations Process for Selecting Board Members. (n.d.). Retrieved February 20, 2020, from https://www.redcross.org/content/dam/redcross/enterprise-assets/pdfs/Board-MemberNominations-Process-17.pdf

Bai, G. (2013). How do board size and occupational background of directors influence social performance in for-profit and nonprofit organizations? Evidence from California hospitals. Journal of Business Ethics, 118(1), 171-187. doi:10.1007/s10551-012-1578-X

Bates-Ballard, P. (2009). Board diversity: Your biggest challenge. Nonprofit World, 27(3), 24.

Bernstein, R. S., Buse, K., \& Bilimoria, D. (2016). The impact of CEO tenure and effective board performance on organizational change. American Journal of Management, 16(4), 26.

BoardSource. (1999). Perspectives on Nonprofit Diversity. Retrieved from https://www.boardsource.org/dl.asp?document_id=511

BoardSource. (2011). The nonprofit board answer book: A practical guide for board members and chief executives. Hoboken: John Wiley \& Sons, Incorporated.

Buse, K., Bernstein, R. S., \& Bilimoria, D. (2016). The influence of board diversity, board diversity policies and practices, and board inclusion behaviors on nonprofit governance practices. Journal of Business Ethics, 133(1), 179-191. doi: 10.1007/s10551-014-2352-z

Collier, A. K., (2017). Building a More Diverse Board with Intention. Retrieved from: https://blueavocado.org/board-of-directors/building-a-more-diverse-board-with-intention/

Connell, E.N. (2019). How to Recruit, Engage, and Retain Millennial Board Members. Retrieved from: https://philanthropynewsdigest.org/columns/the-sustainable-nonprofit/how-to$\underline{\text { recruit-engage-and-retain-millennial-board-members }}$ 
Recruiting For Success. Does Board Diversity Matter?

Creary, S. J., McDonnell, Mary-Hunder., Ghai, S., Scruggs, J. (2019). When and Why Diversity Improves Your Board's Performance, Harvard Business Review. March 27, 2019

Forbes, N. (2015). Diversity, Equity \& Inclusion: A Growing Responsibility for Philanthropic Foundations in the USA. In Leading Across Borders and Generations. Proceedings of the 2015 Annual Conference of International Leadership Association. Barcelona, Spain: International Leadership Association, Inc.

Gallego-Álvarez, I., García-Sánchez, I. M., \& Rodríguez-Dominguez, L. (2019). The influence of gender diversity on corporate performance. Revista De Contabilidad: Spanish Accounting Review, 13(1) doi:10.1016/S1138-4891(10)70012-1

Gill, M. (2007). Governance Models, Board Types, or Best Practices? Charity Village Ltd. Retrieved from https://charityvillage.com/cms/content/topic/governance_models_board types_or_best_p ractices \#.Xe8gmW5FxPY

Guo, C., Brown, W. A., Ashcraft, R. F., Yoshioka, C. F., \& Dong, H. D. (2011). Strategic human resources management in nonprofit organizations. Review of Public Personnel Administration, 31(3), 248-269. doi:10.1177/0734371X11402878

Harris, E. E. (2014). The impact of board diversity and expertise on nonprofit performance. Nonprofit Management and Leadership, 25(2), 113-130. doi:10.1002/nml.21115

Horobiowski, R. R. (2004). The experiences of for-profit executives that served on nonprofit boards of directors (Order No. 3133614). Available from ABI/INFORM Collection. (305089910). Retrieved from http://libraryproxy.quinnipiac.edu/login?url=https://searchproquest-com.libraryproxy.quinnipiac.edu/docview/305089910?accountid=13381

Horwitz, S. K., \& Horwitz, I. B. (2007). The effects of team diversity on team outcomes: A metaanalytic review of team demography. Los Angeles, CA: Sage Publications. doi:10.1177/0149206307308587

Katmon, N., Mohamad, Z. Z., Norwani, N. M., \& Farooque, O. A. (2019). Comprehensive Board Diversity and Quality of Corporate Social Responsibility Disclosure: Evidence from an Emerging Market. Journal of Business Ethics, 157(2), 447-481. https://doiorg.stanford.idm.oclc.org/10.1007/s10551-017-3672-6

Kohn, A., 1993. Why Incentive Plans Cannot Work. Retrieved from URL: https://hbr.org/1993/09/why-incentive-plans-cannot-work 
Recruiting For Success. Does Board Diversity Matter?

Mckay, P. F., \& Avery, D. R. (2005). Warning! diversity recruitment could backfire. Journal of Management Inquiry, 14(4), 330-336. doi:10.1177/1056492605280239

Michel, G., \& Rieunier, S. (05). Nonprofit brand image and typicality influences on charitable giving. Journal of Business Research, 65(5), 701-707.

Milde, K., \& Yawson, R. M. (2017). Strategies for Social Media Use in Nonprofits. Journal of Management Policy and Practice, 18(1), 19-27. https://doi.org/https://doi.org/10.33423/jmpp.v18i1.1779

Miller-Stevens, K., \& Ward, K. D. (2019). Nonprofit board members' reasons to join and continue serving on a volunteer board of directors. Journal of Nonprofit \& Public Sector Marketing, 31(1), 61-83. doi:10.1080/10495142.2018.1526734

NIELSEN, B. B., \& NIELSEN, S. (2013). Top management team nationality diversity and firm performance: A multilevel study. Strategic Management Journal, 34(3), 373-382. doi: $10.1002 /$ smj.2021

Ostrower, F. (2007). NONPROFIT GOVERNANCE IN THE UNITED STATES Findings on Performance and Accountability from the First National Representative Study. Retrieved from URL: https://www.urban.org/sites/default/files/publication/46516/411479Nonprofit-Governance-in-the-United-States.PDF

Price, N. (2018). The Different Nonprofit Government Models. BoardEffect. Retrieved from https://www.boardeffect.com/blog/different-nonprofit-governance-models/

Ruivo, P., Oliveira, T., \& Neto, M. (2015). Using resource-based view theory to assess the value of ERP commercial-packages in SMEs. Computers in Industry, 73, 105-116. doi:10.1016/j.compind.2015.06.001

Trower, C., Eckel, Peter., Making Board Accountable for themselves, Dec. 16, 2016. https://boardsource.org/fundamental-topics-of-nonprofit-board-service/oversightaccountability/

Watson, W. E., \& Kumar, K. (1992). Differences in decision making regarding risk taking: A comparison of culturally diverse and culturally homogeneous task groups. International Journal of Intercultural Relations, 16(1), 53-65. doi:10.1016/0147-1767(92)90005-F

Worth, Michael J., (2019). Nonprofit Management: Principles and Practice (Fifth Edition). Thousand Oaks, CA: Sage Publications, Inc. 
Recruiting For Success. Does Board Diversity Matter?

Yawson, R. M. (2019). Human Resource Development and Executive Leadership Succession Planning in Nonprofits. In Proceedings of the 56th Annual Eastern Academy of Management Conference (pp. 1-16). Wilmington, Delaware: Eastern Academy of Management. https://doi.org/10.31124/advance.7910552.v1 